\title{
Perilaku Pemilih Pada Pemilihan Umum Gubernur Sumatera Utara Tahun 2018 di Kecataman Galang
}

\section{The Voter Behavior in Governor's North Sumatera Election in 2018 at Galang District}

\author{
Dita Mandasari*, Mhd. Thamrin Nasution \& Walid Musthafa Sembiring \\ Program Studi Ilmu Pemerintahan, Fakultas Ilmu Sosial dan Ilmu Politik, \\ Universitas Medan Area, Indonesia
}

\begin{abstract}
Abstrak
Penelitian ini dilatar belakangi oleh adanya sebuah fenomena yang menarik untuk dicermati, yaitu kemenangan pasangan calon Edy Rahmayadi dan Musa Rajekshah di Kecamatan Galang, dimana Kecamatan Galang merupakan kecamatan yang multietnis dan agama. Teori-teori yang digunakan dalam penelitian ini mencakup uraian teori tentang pemilihan umum, perilaku pemilih, dan partisipasi pemilih. Populasi penelitian ini adalah warga masyarakat yang berdomisili di Kecamatan Galang dan terdaftar sebagai pemilih pada pemilihan umum Gubernur Sumatera Utara Tahun 2018, dan sampel yang digunakan dalam penelitian adalah 100 orang. Metode penelitian yang digunakan adalah metode kuantitaitf. Hasil penelitian bahwa berdasarkan analisa dan evaluasi diperoleh bahwa agama (faktor sosiologis), citra/figur calon (faktor psikologis), dan prestasi calon (faktor rasional) memiliki hubungan yang signifikan dengan perilaku pemilih pada pemilihan umum Gubernur Sumatera Utara di Kecamatan Galang.

Kata Kunci: Perilaku Pemilih, Pemilihan Umum
\end{abstract}

\begin{abstract}
This research based on a phenomenon the victory of candidate Edy Rahmayadi and Musa Rajekshah in Galang. Galang, where is a town in multi ethnic and religion. Theories used in this study are the theory about the general election, the behavior of voters, and the participation of voters. The population of this research are the citiziens who are domicile in Galang and registered as a voter in 2018 north sumatera governor general election and used 100 sample in this study. The research method used is a quantitative method. The results of research that based on the analysis and evaluation obtained show that religion (the sociological factors), image/figure of a candidate (psychological factors), and the achievements of the candidate (rational factors) have a significant relationship with the behavior of the voters at the general election the Governor of North Sumatra in Galang
\end{abstract}

Keywords: Voter's Behavior, General Election

How to Cite: Mandasari, D. Nasution, M.T. \& Sembiring, W.M. (2019). Perilaku Pemilih Pada Pemilihan Umum Gubernur Sumatera Utara (GUBSU) Tahun 2018 di Kecataman Galang. Jurnal Ilmu Pemerintahan, Administrasi Publik, Ilmu Komunikasi (JIPIKOM), 1(1) 2019: 73-80,

*E-mail: ditamandasari@gmail.com

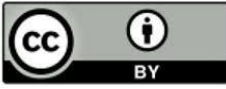




\section{PENDAHULUAN}

Pemilihan Umum (Pemilu) merupakan pemilihan yang diselenggarkan secara langsung, bebas, rahasia, jujur dan adil guna menghasilkan pemerintahan negara yang demokratis berdasarkan Pancasila dan Undang-Undang Dasar Negara Republik Indonesia tahun 1945. Pemilihan kepala daerah atau yang biasa disebut PILKADA atau Pemilukada dilakukan secara langsung oleh penduduk daerah administratif setempat yang memenuhi syarat. Pemilihan kepala daerah dilakukan satu paket bersama dengan wakil kepala daerah. Kepala daerah dan wakil kepala daerah yang antara lain Gubernur dan wakil gubernur untuk provinsi, Bupati dan wakil bupati untuk kabupaten, serta Wali kota dan wakil wali kota untuk kota. Pilkada diselenggarakan oleh Komisi Pemilihan Umum (KPU) Provinsi dan KPU Kabupaten/Kota dengan diawasi oleh Panitia Pengawas Pemilihan Umum (Panwaslu) Provinsi dan Panwaslu Kabupaten/Kota.

Pelaksanaan Pemilihan Umum Kepala Daerah Sumatera Utara di Kecamatan Galang, ada sebuah fenomena yang menarik untuk dicermati, yaitu kemenangan pasangan calon Edy Rahmayadi dan Musa Rajekshah. Dimana pasangan calon Edy Rahmayadi dan Musa Rajekshah yang tidak berafiliasi secara langsung dengan etnis yang ada di Kecamatan Galang justru berhasil memenangkan perolehan suara terbanyak di Kecamatan Galang yang notabene mayoritas penduduknya bersuku Jawa dan Batak. Padahal jika dilihat dari seluruh pasangan calon yang ada, terdapat pasangan calon nomor urut dua yang berasal dari suku Jawa dan Batak. Dari sisi populeritas, Djarot Saiful Hidayat sebagai mantan Gubernur Ibukota yang telah dapat dilihat kinerja dan prestasi saat memimpin Provinsi DKI Jakarta juga tak mampu mengangkat suara pasangan ini.

Pemilihan (election), sering dipandang sebagai "the heart of the political process", demikian juga dari sisi lain baha pemilihan itu merupakan lambang, sekaligus tolak ukur dan praksis (implementasi) dari prinsip-prinsip demokrasi. Hasil pemilihan umum yang diselenggarakan dalam suasana akurat partisipasi srta aspirsi masyarakat Sitepu (2012). Pemilihan umum (general election) itu sendiri diakui secara global, sebagai sebuah arena untuk membentuk demokrasi perwakilan, serta menggelar pergantian pemerintah secara berkala. Menurut teori demokrasi minimalis, sebagaimana yang dijelaskan oleh Joseph Schumpeter bahwa pemilihan umum adalah sebuah arena yang mewadahi kompetisi antara aktor-aktor politik yang meraih kekuasaan partisipasi politik rakyat untuk menentukan pilihan serta liberalisasi hak-hak sipil dan politik warga negara.

Demokrasi merupakan tatanan hidup bernegara yang menjadi pilihaan Negaranegara di dunia pada umumnya. Demokrasi lahir dari tuntutan masyarakat barat akan persamaan hak dan kedudukan yang sama di depan hukum. Hal ini terjadi karena pada masa sebelum adanya deklarasi Amerika dan Perancis, setiap warga dibeda - bedakan kedudukannya baik di depan hukum maupun dalam tatanan social masyaraka (Irawan, 2007). Demorasi merupakan bentuk pemerintahan politik yang bentuk kekuasaan memerintahnya berasal dari rakyat, baik secara langsung (demokrasi langsung) atau perakilan (demokrasi perwakilan). Istilah ini berasal dari bahasa Yunani yaitu demokratia (kekuasaan rakyat), yang dibentuk dari kata demos (rakyat) dan kratos 
(kekuasaan). Merujuk pada sistem politik yang muncul pada pertengahan abad ke 5 dan abad ke 4 SM di kota Yunani khususnya Athena (Azra, 2005).

Demokrasi dan Pemilihan Umum memiliki kaitan yang sangat erat, dalam demokrasi salah satu parameter untuk mencapai tujuan dari demokrasi adalah Pemilihan Umum yang diartikan sebagai rekrutmen jabatan politik atau publik harus dilakukan dengan pemilihan umum (pemilu) yang diselenggarakan secara teratur dengan tenggang waktu yang jelas, kompetitif, jujur dan adil (Hasibuan, Kadir \& Nasution, 2018; Zega, Muda, Batubara \& Suharyanto, 2018). Dalam konteks pemilu, mekanisme demokrasi bisa sangat mengecewakan hasilnya mengingat mayoritas rakyat pendidikannya rendah, sebagian elite politik hanya memikirkan diri dan kelompoknya sehingga yang terjadi adalah manipulasi dan mobilisasi massa yang naif. Lebih mengecewakan lagi, jika kemiskinan rakyat itu dimanipulasi melalui politik uang sehingga hak dan kedaulatan rakyat yang merupakan roh demokrasi telah dibajak, dirampas, dan dibunuh oleh para elit politisi dengan senjata uang. Menurut Hidayat (2006) demokrasi sarat akan nilai-nilai, meliputi: Kejujuran, kebebasan, kepatuhan, Persamaan, toleransi, perdamaian, dan fatsoen (tata karma).

Budiarjo (2008) mendefinisikan perilaku pemilih sebagai kegiatan seseorang atau kelompok orang untuk ikut serta secara aktif dalam kehidupan politik, antara lain dengan jalan memilih pemimpin negara dan secara langsung atau tidak langsung mempengaruhi kebijakan pemerintah (public policy). Menurut Nugraheni (2016) perilaku pemilih yakni kecenderungan pilihan rakyat dalam pemilihan umum serta latar belakang mengapa mereka melakukan pilihan itu. Kemudian Nasrudin dalam Nugraheni (2016) berpendapat bahwa perilaku pemilih merupakan tindakan para pemilih dalam memberikan suaranya pada pemilihan kepala daerah. Secara lebih mendalam Gaffar dalam Nugraheni (2016) menyatakan bahwa perilaku memilih merupakan bentuk partisipasi politik aktif yang paling kecil dari masyarakat, karena hal itu hanya menuntut suatu keterlibatan minimal yang akan berhenti jika pemberian suara telah terlaksanana. Partisipasi masyarakat merupakan implementasi kedaulatan rakyat yang dimanifestasikan oleh keterlibatan pemilih dalam pesta demokrasi. Semakin tinggi partisipasi menandakan bahwa rakyat mengikuti, memahami, dan melibatkan diri dalam kegiatan kenegaraan (Kusmanto, 2013; Kusmanto, 2014; Suharyanto, 2014; Wardhani, 2018; Ivanna, Pardede \& Iqbal 2018; Suharyanto, 2016).

Secara teoritis ada dua penjelasan teori mengapa seseorang tidak ikut memilih dalam pemilihan. Penjelasan pertama bersumber dari teori-teori mengenai perilaku pemilih (voter behavior). Penjelasan ini memusatkan perhatian pada individu. Besar kecilnya partisipasi pemilih (voting turnout) dilacak pada sebab-sebab dari individu pemilih. Secara umum analisa- analisa mengenai "voting behaviour" atau perilaku pemilih didasarkan pada tiga pendekatan atau model Kamil (2016), yaitu: Pendekatan Sosiologi, Pendekatan Psikologi, dan Pendekatan Rasional.

Partisipasi merupakan salah satu aspek penting demokrasi. Partisipasi masyarakat menjadi komponen utama dalam setiap pelaksanaan pemilu hal ini dikarenakan partisipasi mengandaikan adanya keterlibatan masyarakat secara nyata dalam proses pemilu yang secara politik menjadi legitimasi bagi perjalanan politik 
kebangsaan di tanah air Kamil (2016). Partisipasi merupakan taraf partisipasi politik warga masyarakat dalam kegiatan-kegiatan politik baik yang bersifat aktif maupun pasif dan bersifat langsung maupun yang bersifat tidak langsung guna mempengaruhi kebijakan pemerintah. Herbert McClosky seorang tokoh masalah partisipasi berpendapat bahwa partisipasi politik adalah kegiatan-kegiatan sukarela dari warga masyarakat melalui mana mereka mengambil bagian dalam proses pemilihan penguasa, dan secara langsung atau tidak langsung, dalam proses pembentukan kebijakan umum Budiarjo (2008).

Berdasarkan uraian latar belajang dan didukung dengan tinjauan teoritis yang telah dipaparkan sebelumnya, maka hipotesis dalam penelitian ini adalah:

1. Hipotesis nol $\left(\mathrm{H}^{0}\right)$ adalah tidak ada hubungan antara faktor sosiologis (umur, agama, jenis kelamin, pekerjaan, etnis/suku, pendidikan) dengan perilaku pemilih pada PILGUBSU 2018 di Kecamatan Galang.

2. Hipotesis Alternatif (Ha) ada hubungan antara faktor sosiologis (umur, agama, jenis kelamin, pekerjaan, etnis/suku, pendidikan) dengan perilaku pemilih pada PILGUBSU 2018 di Kecamatan Galang.

3. Hipotesis nol (Ho) adalah tidak ada hubungan antara faktor psikologis (partai pilihan dan citra/figur calon) dengan perilaku pemilih pada PILGUBSU 2018 di Kecamatan Galang.

4. Hipotesis Alternatif ( $\mathrm{Ha}$ ) adalah ada hubungan antara faktor psikologis (partai pilihan dan citra/figur calon) dengan perilaku pemilih pada PILGUBSU 2018 di Kecamatan Galang

5. HIpotesis nol (H0) adalah tidak ada hubungan antara faktor rasional (visi misi dan prestasi calon) dengan perilaku pemilih pada PILGUBSU 2018 di Kecamatan Galang.

6. Hipotesis Alternatif $(\mathrm{Ha}$ ) adalah ada hubungan antara faktor rasional (visi misi dan prestasi calon) dengan perilaku pemilih pada PILGUBSU 2018 di Kecamatan Galang.

\section{METODE PENELITIAN}

Metode penelitian ini menggunakan pendekatan kuantitatif dengen jenis deskritif. Lokasi penelitian yang ditetapkan oleh peneliti di Kecamatan Galang Kabupaten Deli Serdang. Teknik sampling yang digunakan dalam penelitian ini adalah teknik non probability sampling dengan jenis accidental sampling dengan menggunkan kuisioner untuk pengumpulan data. Jumlah Pemilih yang berpartisipasi dalam pemilihan umum Gubernur Sumatera Utara sebanyak 27.649 Jiwa. Jumlah sampel yang diambil sebanyak 100 orang pemilih dengan rumus slovin (Supriana, 2016:44):

$$
n=\frac{N}{1+N e^{2}}=\frac{27.649}{1+(27.649)(0,1)^{2}}=100
$$

Keterangan:

$\mathrm{n}=$ Ukuran Sempel

$\mathrm{N}=$ Ukuran Populasi

$\mathrm{e}=$ Kesalahan Pengambilan sampel yang ditolerir $10 \%$

Penelitian ini menggunakan 6 dimensi pengukuran pada variabel Faktor Sosiologi (X1) 
1. Umur

2. Agama

3. Jenis Kelamin

4. Pekerjaan

5. Etnis/sssukuuu

6. Pendidikan

Variabel Faktor Psikologi (X2) menggunakan 2 dimensi pengukuran, yaitu:

1. Partai Pilihan Pemilih

2. Citra/figure calon yang meliputi gaya berbicara, gaya penampilan, dan pesona fisik

3. Variabel Fkator Rasional (X3) menggunakan 2 dimensi pengukuran, yaitu:

4. Visi dan Misi calon Gubernur

5. Prestasi kandidat calon gubernur

Sedangkan pada variabel Perilaku Pemilih (Y) yaitu Pilihan pemilih terhadap Calon gubernur Sumatera Utara yaitu pasangan calon nomor urut 1 Edy RahmayadiMusa Rajekshah atau pasangan calon nomor urut 2 Djarot Saiful Hidayat-Sihar Sitorus.

Analisis data menggunakan analisis Bivariat adalah analisis yang digunakan untuk mengetahui hubungan anatara variabel bebas dengan variabel terikat dengan menggunakan uji statististik. Uji statistik yang digunakan dalam penelitian ini adalah uji Chi Square. Menggunakan bantuan perangkat lunak yaitu SPSS 17 berbentuk komputer dengan signifikan $\mathrm{p}>0,05 \%$ (dengan taraf kepercayaan 95\%).

\section{HASIL DAN PEMBAHASAN}

\section{Hubungan antara Faktor Sosilogis terhadap Perilaku Pemilih}

Tabel 1.1 Hubungan Faktor Sosiologis terhadap Perilaku Peemilih

\begin{tabular}{cllllll}
\hline Variabel & Umur & Agama & J.Kelamin & Pekerjaan & Etnis & pendidikan \\
\hline $\begin{array}{c}\text { Preilaku } \\
\text { (Y) }\end{array}$ & $\mathrm{X} 1.1->\mathrm{Y}$ & $\mathrm{X} 1.2->\mathrm{Y}$ & $\mathrm{X} 1.3->\mathrm{Y}$ & $\mathrm{X} 1.4 \_. \mathrm{Y}$ & $\mathrm{X} 1.5->\mathrm{Y}$ & $\mathrm{X} 1.6->\mathrm{Y}$ \\
\cline { 2 - 7 } & 0.319 & 0.002 & 0.336 & 0.597 & 0.350 & 0.119 \\
\hline Koefisien kontingensi & 000 & 0.301 & 000 & 000 & 000 & 000 \\
\hline
\end{tabular}

Sumber : Data diolah SPSS 17, 2018

Berdasarkan data pada tabel 1.1 diketahui bahwa nilai probabilitas chi-square umur (X1.1) terhadap Perilaku Pemilih (Y) sebesar 0.319. Nilai probabilitas tersebut lebih besar dari nilai nilai $\alpha=0,05$, sehingga Ho diterima dan Ha ditolak. Maka dapat disimpulkan bahwa tidak ada hubungan yang signifikan umur dengan perilaku pemilih pada Pemilihan Umum Gubernur Sumatera Utara 2018 di Kecamatan Galang. Sedangkan nilai probralitias Agama (X1.2) terhadap Perilaku Pemilih (Y) dilihat dari nilai probablitias chi-square sebesar 0,002. Nilai probabilitas tersebut lebih kecil dari nilai nilai $\alpha=0,05$, sehingga Ha diterima dan Ho ditolak. Maka dapat disimpulkan bahwa ada hubungan yang signifikan agama dengan perilaku pemilih pada Pemilihan Umum Gubernur Sumatera Utara 2018 di Kecamatan Galang. Nilai kontengensi symmetric measure pada tabel 1.1 sebesar 0,301 artinya keeratan hubungan antara agama dengan perilaku pemilih sebesar $30,1 \%$.

Hasil Data pada tabel 1.1 menunjukkan bahwa hubungan antara jenis kelamin terhadap perilaku pemilih berdasarkan nilai probabilitas chi-square adalah sebesar 
0,036, nilai probabilitas ini lebih besar dari $\alpha=0,05$ menunjukkan bahwa tidak ada hubungan yang signifikan antara jenis kelamin dengan perilaku pemilih pemilih pada Pemilihan Umum Gubernur Sumatera Utara 2018 di Kecamatan Galang. Sedangkan hubungan antara pekerjaan (X1.4) terhadap perilaku pemilih (Y) dilihat dari nilai probabilitas chi-square adalah sebesar 0,597. Nilai probabilitas tersebut lebih besar dari nilai nilai $\alpha=0,05$. Sehingga pekerjaan tidak berhubungan signifikan terhadap perilaku pemilih pada Pemilihan Umum Gubernur Sumatera Utara 2018 di Kecamatan Galang.

Hasil analisis pengujian hipotesis pada tabel 1.1 menunjukkan bahwa etnis/suku (X1.5) terhadap perilaku pemilih memiliki nilai pobabilitas chi-square sebesar 0,350. Nilai probabilitas tersebut lebih besar dari nilai nilai $\alpha=0,05$, sehingga dapat ilihat bahwa tidak ada hubungan yang signifikan etnis/suku dengan perilaku pemilih pada Pemilihan Umum Gubernur Sumatera Utara 2018 di Kecamatan Galang. Sedangkan variabel pendidikan (X1.6) terhadap perilaku pemilih memiliki nilai probabilitas chisquare sebesar 0,119. Nilai probabilitas tersebut lebih besar dari nilai nilai $\alpha=0,05$, sehingga diketahui bahwa tidak ada hubungan yang signifikan pendidikan dengan perilaku pemilih pada Pemilihan Umum Gubernur Sumatera Utara 2018 di Kecamatan Galang.

\section{Hubungan antara Variabel Psikologi terhadap Perilaku pemilih}

Tabel 1.2 Hubungan Antara Variael Faktor Psikologi terhadap Perilaku Pemilih

\begin{tabular}{lccc}
\hline Variabel & Partai pilihan & Citra/figure calon \\
\hline Perilaku & $\mathrm{X} 2.1->\mathrm{Y}$ & $\mathrm{X} 2.2->\mathrm{Y}$ \\
\cline { 2 - 3 }$(\mathrm{Y})$ & 0.086 & 0.010 \\
\hline Koefisien Kontingensi & 000 & 0.290 \\
\hline
\end{tabular}

\section{Sumber: Data diolah SPSS 17, 2018}

Berdasarkan tabel 1.2 diketahui bahwa hasil analisis data pengujian hipotesis meunjukkan nilai probabilitas chi-square sebesar 0,086. Nilai probabilitas tersebut lebih besar dari nilai nilai $\alpha=0,05$, sehingga Ho diterima dan Ha ditolak. Maka dapat disimpulkan bahwa tidak ada hubungan yang signifikan partai pilihan dengan perilaku pemilih pada Pemilihan Umum Gubernur Sumatera Utara 2018 di Kecamatan Galang. Selain itu, diketahui nilai probabilitas chi-squre citra/figure calon pilihan terhadap perilaku pemilih sebesar 0,010 . Nilai probabilitas tersebut lebih kecil dari nilai nilai $\alpha=$ 0,05, sehingga Ha diterima dan Ho ditolak. Maka dapat disimpulkan bahwa ada hubungan yang signifikan citra/figur calon dengan perilaku pemilih pada Pemilihan Umum Gubernur Sumatera Utara 2018 di Kecamatan Galang. Nilai kontengensi pada tabel Symmetric Measures sebesar 0,290 artinya keeratan hubungan antara citra/figur calon dengan perilaku pemilih sebesar $29,0 \%$.

\section{Hubungan antara Variabel Faktor Rasional terhadap Perilaku Pemilihan}

Tabel 1.3 Hubungan antara Fakor Rasional terhadap Perilaku Pemilih

\begin{tabular}{ccc}
\hline \multicolumn{1}{l}{$\begin{array}{c}\text { Variabel } \\
\begin{array}{c}\text { Preilaku } \\
\text { (Y) }\end{array}\end{array}$} & Visi misi calon & Prestasi Calon \\
\hline & 0.493 & $\mathrm{X} 3.2->\mathrm{Y}$ \\
\hline Koefisien Kontingensi & 000 & 0.003 \\
\hline Sumber: data diolah SPSS & 17,2018 & 0.283 \\
\hline
\end{tabular}


Berdasarkan dari tabel 1.3 diketahui bahwa nilai probabilitas chi-square VIsi misi calon (X3.1) terhadap perilaku pemilih (Y) sebesar 0,493. Nilai probabilitas tersebut lebih besar dari nilai nilai $\alpha=0,05$, sehingga Ho diterima dan Ha ditolak. Maka dapat disimpulkan bahwa tidak ada hubungan yang signifikan visi misi dengan perilaku pemilih pada Pemilihan Umum Gubernur Sumatera Utara 2018 di Kecamatan Galang. Sedangkan nilai probabilitas chi-square prestasi calon (X3.2) terhadap Perilaku pemilih (Y) sebesar 0,003. Nilai probabilitas tersebut lebih kecil dari nilai nilai $\alpha=0,05$, sehingga Ha diterima dan Ho ditolak. Maka dapat disimpulkan bahwa ada hubungan yang signifikan prestasi calon dengan perilaku pemilih pada pemilihan umum Gubernur Sumatera Utara2018 di Kecamatan Galang. Nilai Kontingensi pada gtabel symmetric measure sebesar 0,283 yang berarti keeratan hubungan antr prestasi calon terhadap perilaku pemilih sebesar $28,3 \%$.

\section{SIMPULAN}

Agama sebagai bagian dari faktor sosiologis memiliki hubungan yang signifikan dengan perilaku pemilih. Sedangkan faktor sosiologis lainnya seperti umur, jenis kelamin, pekerjaan, etnis/suku, dan pendidikan ternyata tidak memiliki hubungan yang signifikan dengan perilaku pemilih. Citra/figur calon sebagai bagian dari faktor psikologis memiliki hubungan yang signifikan dengan perilaku pemilih. Sedangkan partai pilihan tidak memiliki hubungan yang signifikan dengan perilaku pemilih. Prestasi calon sebagai bagian dari faktor rasional yang memiliki hubungan yang signifikan dengan perilaku pemilih. Sedangkan visi misi tidak memiliki hubungan yang signifikan dengan perilaku pemilih

\section{DAFTAR PUSTAKA}

Azra, A. (2005). Dmokrasi, Hak Asasi Manusia, dan Masyarakat Madani. Jakarta: Prenada Media.

Budiarjo, M. (2008). Dasar-Dasar Ilmu Politik. Jakarta: Gramedia Pustaka Utama.

Hasibuan, S.J. Kadir, A. \& Nasution, M.H.T. (2018). Strategi Komisi Pemilihan Umum Provinsi Sumatera Utara Dalam Meningkatkan Partisipasi Masyarakat Pada Pemilihan Gubernur Sumatera Utara 2018. PERSPEKTIF, 7 (1): 1-5.

Hidayat, K. (2006). Pendidikan Kewarganegaraan. Jakarta: Peranada Media.

Irawan, B. (2007). Perkembangan Demokrasi di Negara Indonesia. Jurnal Hukum dan Dinamika Masyarakat, 5(1), 00.

Ivanna, J. Pardede, A.J. \& Iqbal, M. (2018). Peran Media Cetak dalam Meningkatkan Partisipasi Politik Di Kelurahan Bandar Selamat Kecamatan Medan Tembung Kota Medan. Journal of Education, Humaniora and Social Sciences (JEHSS). 1 (1): 25-35.

Kamil, H. (2016). Partisipasi Pemilih dalam Pemilu 2014. Komisi Pemilihan Umum, --.

Komisi Independen Pemilihan Kabupaten Aceh Singkil. 2014. Analisis Faktor-Faktor Yang Mempengaruhi Perilaku Pemilih dalam Pemilu Kepala Daerah Tahun 2014 Di Kabupaten Aceh Singkil (Studi Kasus Pada Daerah Pemilihan di Kecamatan Gunung Meriah. Komisi Pemilihan Umum.

Kusmanto, H., (2013). Peran Badan Permusyawaratan Daerah dalam Meningkatkan Partisipasi Politik Masyarakat, JPPUMA: Jurnal Ilmu Pemerintahan dan Sosial Politik UMA (Journal of Governance and Political UMA), 1 (1): 41-47.

Kusmanto, H, (2014). Partisipasi Masyarakat dalam Demokasi Politik, JPPUMA: Jurnal Ilmu Pemerintahan dan Sosial Politik UMA (Journal of Governance and Political UMA), 2 (1): 77-89

Nugraheni, D. (2016). Anlisis Perilaku Pemilih dalam Pemilihan Kepala Desa. Skripsi Institut Pertanian Bogor, 00.

Sitepu, A. (2012). Studi Ilmu Politik. Yogyakarta: Graha Ilmu. 
Suharyanto, A., (2014). Partisipasi Politik Masyarakat Tionghoa dalam Pemilihan Kepala Daerah, JPPUMA: Jurnal Ilmu Pemerintahan dan Sosial Politik UMA (Journal of Governance and Political UMA), 2 (2): 166-175

Suharyanto, A., (2016), Surat Kabar Sebagai Salah Satu Media Penyampaian Informasi Politik pada Partisipasi Politik Masyarakat, Jurnal Administrasi Publik, 6 (2): 123-136.

Supriana, T. (2016). Metode Penelitian Sosial Ekonomi. Medan: USU Press.

Wardhani, P.S.N. (2018). Partisipasi Politik Pemilih Pemula dalam Pemilihan Umum. Jurnal Pendidikan Ilmu-Ilmu Sosial, 10 (1): 57-62.

Zega, M.A. Muda, I. Batubara, B.M. \& Suharyanto, A. (2018). Pengaruh Program Rumah Pintar Pemilu Terhadap Partisipasi Politik Masyarakat Pada Kantor Komisi Pemilihan Umum Kota Medan, PERSPEKTIF, 7 (2): 60-65. 